\title{
Effects of nandrolone decanoate on expression of steroidogenic enzymes in the rat testis
}

\author{
TaeSun Min ${ }^{1}$ and Ki-Ho Lee ${ }^{2, *}$
}

* Corresponding Author: Ki-Ho Lee Tel: +82-42-259-1643, Fax: +82-42-259-1649

E-mail: kiholee@eulji.ac.kr

${ }^{1}$ Faculty of Biotechnology, SARI, Jeju National University, Jeju 63243, Korea

2 Department of Biochemistry and Molecular Biology, College of Medicine, Eulji University, Daejeon 34824, Korea

ORCID

TaeSun Min

https://orcid.org/0000-0002-3998-7493 Ki-Ho Lee

https://orcid.org/0000-0002-3495-5126

Submitted Dec 13, 2017; Revised Jan 5, 2018; Accepted Feb 5, 2018
Objective: Nandrolone decanoate (ND) is an anabolic-androgenic steroid frequently used for clinical treatment. However, the inappropriate use of ND results in the reduction of serum testosterone level and sperm production. The suppressive effect of ND on testosterone production has not been investigated in detail. The present study was designed to examine the effect of ND on the expression of steroidogenic enzymes in the rat testis.

Methods: Male Sprague Dawley rats at 50 days of age were subcutaneously administrated with either 2 or $10 \mathrm{mg}$ of ND/kg body weight/week for 2 or 12 weeks. The changes of transcript and protein levels of steroidogenic enzymes in the testis were determined by real-time polymerase chain reaction and western blotting analyses, respectively. Moreover, immunohistochemical analysis was employed to determine the changes of immunostaining intensity of these enzymes. The steroidogenic enzymes investigated were steroidogenic acute regulatory protein, cytochrome P450 side chain cleavage enzyme, 17 $\alpha$-hydroxylase, $3 \beta$-hydroxysteroid dehydrogenase, and cytochrome $\mathrm{P} 450$ aromatase.

Results: The treatment of ND resulted in depletion of Leydig cells and sloughing of germ cells in the testis. The ND treatment caused significant expressional decreases of steroidogenic enzymes at transcript and protein levels, and the destructive effects of ND on the testis were more apparent with a higher dose and a longer period of the treatment. Evident reduction of immunostaining intensity present in Leydig cells was clearly detected by the ND treatment. Conclusion: The exposure to ND in young male results not only in histological changes of the testis but also in aberrant gene expression of testicular steroidogenic enzymes, consequently leading into the reduction of testosterone production in the testis and thus likely disruption of spermatogenesis.

Keywords: Testis; Male Fertility; Steroidogenic Enzymes; Leydig Cell; Gene Expression; Nandrolone Decanoate

\section{INTRODUCTION}

The synthesis of sex steroid hormones, testosterone and estrogen, in the testis is primarily occurred within Leydig cells and requires a series of actions of steroidogenic enzymes [1]. The cholesterol is first imported into the mitochondria by steroidogenic acute regulatory protein (StAR), and cytochrome P450 side chain cleavage enzyme (CYP11A1) then cleaves the side-chain of cholesterol to produce pregnenolone [1]. The conversion of pregnenolone to testosterone is achieved by a chain reaction of several enzymes, including $3 \beta$-hydroxysteroid dehydrogenase (HSD3B1), 17 $\alpha$-hydroxylase (CYP17), and 17 $\beta$-hydroxysteroid dehydrogenase (HSD17B) [1]. The aromatization of the A-ring of testosterone by cytochrome $\mathrm{P} 450$ aromatase (CYP19) is required to produce estradiol $\left(\mathrm{E}_{2}\right)$ from testosterone [1]. Thus, any intrinsic or extrinsic cures affecting the expression and/or activity of these testicular steroidogenic enzymes could influence on the production of sex steroid hormones in male. Indeed, many researches have demonstrated that the exposure to various environmental and syn- 
thetic substances gives an impact on the production of sex steroid hormones by affecting expression of steroidogenic enzymes in the testis.

Nandrolone (19-nortestosterone) is an anabolic-androgenic steroid (AAS), which is structurally and functionally close to testosterone but has 10 times greater anabolic effect than testosterone [2]. Nandrolone is naturally present in the blood and consumable parts, including meat, of boar $[3,4]$ and is also chemically synthesized in a decanoate esterifed form, commercially called nandrolone decanoate (ND). The ND is often used for treatments of several clinical conditions, such as HIVassociated muscle wasting, anemia induced by chronic renal failure, and bone mineral density in elderly osteoporotic women [5]. In spite of such beneficial effects of ND, there are undesirable physiological and psychological outcomes accompanied by the administration of ND, including the deleterious effects of ND in the male and female reproductive systems. Especially, the administration of ND in male often accomplishes impaired spermatogenesis, depletion of Leydig cells, and germ cell sloughing in the testis [6], atrophic change of prostate [7], and reduction of fertility [8]. However, a detailed molecular mechanism defining such harmful effects of ND on the male reproduction has not been established.

The most common endocrinological effect of the exposure to ND is the reduction of serum testosterone level $[8,9]$, likely due to expressional modulation of testicular steroidogenic enzymes by ND administration [10-12]. For example, the decreases of testicular HSD3B and HSD17B activities have been detected with exogenous treatment of ND [10,11]. A recent study has shown significant decreases of testicular StAR, HSD3B1, and CYP17 protein levels by superphysiological doses of ND [12]. In addition, at the superphysiological doses of ND, mRNA levels of Star and Cyp17 have not been changed and expressional level of $H s d 31$ gene has even become increased [12]. However, such inconsistency between mRNA levels and protein levels of testicular steroidogenic enzymes by ND treatment has not been elucidated.

The use of AAS, including ND, in purpose of non-medical desires is considerably increasing among professional athletes and bodybuilders to improve muscle strength and perfor- mance [13]. Also, the uncontrolled use of AAS among nonprofessional people and even teenagers is frequently achieved to enhance physical appearance by temporal quick growth of muscle mass [13]. Even though it is well-documented that the misuse of AAS is strongly associated with the decline of male fertility, primarily starting with a decline of testosterone production in the testis [13], the effect of ND on the expression of steroidogenic enzymes in the testis at fairly low doses and/or for different durations of the exposure has not been thoroughly examined yet.

In the present study, we chiefly attempted to assess expressional changes of several steroidogenic enzymes at mRNA and protein levels by ND treatment at two different doses (low and high) and for two different periods (short and long). Microscopic examination of the testis was accomplished to evaluate the association between histological observations and molecular biological findings acquired from the current research.

\section{MATERIALS AND METHODS}

\section{Experimental design and tissue preparation}

Male Sprague Dawley rats at 40 days of age were purchased from Samtako (OSan, Korea) and individually housed under controlled conditions. The animals were maintained under normal light hours $(14 \mathrm{~L}: 10 \mathrm{D})$ and temperature $\left(22^{\circ} \mathrm{C}\right.$ to $24^{\circ} \mathrm{C}$ ) and given ad libitum access to food and water for experimental period. The ND, in a form of Deca-Durabolin, was obtained from Organon Korea Ltd. (Seoul, Korea). The concentration of ND in a stock solution was $50 \mathrm{mg} / \mathrm{mL}$, and the stock solution was diluted into proper concentrations with peanut oil.

At 50 days of age, the animals were randomly assigned into two experimental groups according to treatment period ( 2 or 12 weeks), and were further divided into 3 subgroups, control group (peanut oil: $\mathrm{n}=5$ ), a low-dose ND treatment group (2 $\mathrm{mg}$ of $\mathrm{ND} / \mathrm{kg}$ body weight/wk: $\mathrm{n}=6$ ), and a high-dose ND treatment group ( $10 \mathrm{mg}$ of $\mathrm{ND} / \mathrm{kg}$ body weight/wk: $\mathrm{n}=6$ ). Body weight was recorded every week to adjust an amount of peanut oil or ND administrated subcutaneously (Table 1),

Table 1. Primer information for real-time PCR

\begin{tabular}{|c|c|c|c|c|}
\hline $\begin{array}{l}\text { Molecule } \\
\text { (GenBank ID) }\end{array}$ & $\begin{array}{l}\text { Forward primer sequence } \\
\left(5^{\prime} \rightarrow 3^{\prime}\right)\end{array}$ & $\begin{array}{l}\text { Reverse primer sequence } \\
\left(5^{\prime} \rightarrow 3^{\prime}\right)\end{array}$ & $\begin{array}{l}\operatorname{Tm} \\
\left({ }^{\circ} \mathrm{C}\right)\end{array}$ & $\begin{array}{l}\text { Expected PCR } \\
\text { size (bps) }\end{array}$ \\
\hline Star (NM_031558) & CTGCTAGACCAGCCCATGGAC (490-510) & TGATTTCCTTGACATTTGGGTTCC (557-580) & 66 & 91 \\
\hline Cyp11a1 (J05156) & AGGTGTAGCTCAGGACTT (530-547) & AGGAGGCTATAAAGGACACC (909-928) & 52 & 399 \\
\hline Cyp17 (M31681) & AGATTGACCAGTACGTAGGCTTCAGCCGAA (1031-1060) & CACATCCAAGTCAAACCTCTGCAGTAGC (1413-1440) & 67 & 410 \\
\hline Hsd3b1 (M38178) & CCCATACAGCAAAAGGATGG (636-655) & GCCGCAAGTATCATGACAGA (766-785) & 55 & 150 \\
\hline Cyp19 (М33986) & GCTTCTCATCGCAGAGTATCCGG (1555-1577) & CAAGGGTAAATTCATTGGGCTTGG (1821-1844) & 62 & 290 \\
\hline
\end{tabular}

PCR, polymerase chain reaction; Star, steroidogenic acute regulatory protein; Cyp11a1, cytochrome P450 side chain cleavage; Cyp 17, cytochrome P450 17a-hydroxylase; Hsd3b1, 3-beta-hydroxysteroid dehydrogenase/delta-5-delta-4 isomerase type I; Cyp19, cytochrome P450 aromatase; Ppia, cyclophilin A. Numbers in parentheses of primer sequences indicate the positions of bases in GenBank sequences. 
and the last injection was carried out at the day of the 2 nd or 12th week. The doses of ND used in the present research were selected based on the literature [5,7-12,14]. The dose of $10 \mathrm{mg}$ of $\mathrm{ND} / \mathrm{kg}$ body weight/wk shows a promising effect on the testis $[7-10,12]$ and is greatly lower than the doses treated for several human clinical symptoms, such as $150 \mathrm{mg}$ of ND/2 weeks for treatment of HIV-associated weight loss and $25 \mathrm{mg}$ of $\mathrm{ND} /$ week for improvement of exercise capacity in patients with chronic obstructive pulmonary disease [14]. In addition, the dose of $2 \mathrm{mg}$ of ND was chosen to determine how much low dose of ND influences on the testis and/or testicular testosterone production. The present study was carried out in accordance with the guide for the care and use of laboratory animals of National Research Council in Korea.

At the end of experiment, the animal was anesthetized by $\mathrm{CO}_{2}$ stunning. Blood sample was obtained by guillotine decapitation, and then serum was collected by centrifugation $(890 \times \mathrm{g})$ for $15 \mathrm{~min}$ at $4^{\circ} \mathrm{C}$. The serum was kept in $-20^{\circ} \mathrm{C}$ until utilized for measurement of testosterone concentration. The testis was rapidly collected and weighted. One testis was fixed in Bouins solution for histological and immunohistochemical analyses and the other was quickly frozen in liquid nitrogen and stored in $-80^{\circ} \mathrm{C}$ until used for real-time polymerase chain reaction (PCR) and western blotting analyses.

\section{Analysis of serum testosterone concentration}

The concentration of testosterone in serum was measured by the enzyme-linked immunosorbent assay (ELISA) method using a DRG ELISA testosterone kit (EIA-1559; DRG International Inc., Mountainside, NJ, USA) according to the manufacturer's instructions. Briefly, $50 \mu \mathrm{L}$ of standard, sample serum, or control were dispensed into the well, followed by an addition of $100 \mu \mathrm{L}$ of enzyme conjugate. After incubation for 1 hour at room temperature, wells were rinsed with diluted washing solution for three times. Next, $150 \mu \mathrm{L}$ of substrate solution were added into the well and then incubated for 15 minutes at room temperature. Measurement of testosterone concentration was performed at $450 \mathrm{~nm}$ in ELISA reader (Microplate Autoreader, BioRad Laboratory, Hercules, CA, USA) after addition of stop solution. All testing materials were triplicated for the assay. The sensitivity and intra- and inter-assay variation coefficients of the kit were 0 to 0.083 $\mathrm{ng} / \mathrm{mL}, 3.28 \%$ to $4.16 \%$, and $4.73 \%$ to $9.94 \%$, respectively.

Total RNA isolation and real-time polymerase chain reaction analysis

Total RNA was isolated in accordance with the instruction provided with TRIzol RNA extraction solution (Invitrogen, Carlsbad, CA, USA). Briefly, about $50 \mathrm{mg}$ of testis was homogenized in $1 \mathrm{~mL}$ of TRIzol solution using a Polytron homogenizer (Fisher Scientific, Pittsburgh, PA, USA). After centrifugation at $16,609 \times \mathrm{g}\left(4^{\circ} \mathrm{C}\right)$ for $20 \mathrm{~min}$, total RNA was extracted by chloroform and isopropanol precipitation. The RNA pellet was suspended in RNA storage buffer (Ambion, Austin, TX, USA) and stored in $-80^{\circ} \mathrm{C}$. The quantity and quality of total RNA were determined by UV spectrophotometer (Eppendorf, New York, NY, USA) and 1.2\% gel electrophoresis, respectively.

The reverse transcription (RT) reaction was performed with $1 \mu \mathrm{g}$ of total RNA according to the instruction in the ImPromII RT system (Promega, Madison, WI, USA). Using oligo-dT primer, a mixture of $\mathrm{RT}$ reaction in a total volume of $20 \mu \mathrm{L}$ was sequentially exposed at $25^{\circ} \mathrm{C}$ for $5 \mathrm{~min}, 42^{\circ} \mathrm{C}$ for $1 \mathrm{~h}$, and $70^{\circ} \mathrm{C}$ for $15 \mathrm{~min}$ to generate complementary DNA (cDNA). The real-time PCR was carried out in a mixture of $1 \mu \mathrm{L}$ of cDNA, $0.75 \mathrm{U}$ of GoTaq DNA polymerase (Promega, USA), $5 \mu \mathrm{L}$ of $5 \times$ buffer, $0.2 \mathrm{mM}$ of deoxyribonucleotide triphosphate (Promega, USA), $2.5 \mu \mathrm{L}$ of $3,000 \times$ SYBR Green I (BMA, Rockland, ME, USA), and 10 pmol of each primer. A total volume of real-time PCR mixture was $25 \mu \mathrm{L}$, and the realtime PCR program employed an initial step at $95^{\circ} \mathrm{C}$ for $5 \mathrm{~min}$ for pre-denaturation, followed by denaturation at $94^{\circ} \mathrm{C}$ for 30 $\mathrm{s}$, annealing at $\mathrm{T}_{\mathrm{m}}$ for $30 \mathrm{~s}$, and extension at $72^{\circ} \mathrm{C}$ for $30 \mathrm{~s}$ using the PTC-200 Chromo 4 real-time system (BioRad Laboratories, USA). At the end of PCR, an additional extension step was followed at $72^{\circ} \mathrm{C}$ for $10 \mathrm{~min}$. Oligonucleotide primers were designed by using Primer 3 software (Whitehead Institute/ MIT Center for Genomes Research, Cambridge, MA, USA; http://www.bioneer.co.kr/cgi-bin/primer/primer3.cgi). Cyclophilin A (Ppia) was included as an internal PCR control, and information for PCR primers is summarized in Table 2. No RNA, no cDNA template, and no primer controls were also included for PCR quality control purpose. The PCR products were fractionated on $1.2 \%$ agarose gel to check the sizes and qualities. Quantitative values of real-time PCR results were

Table 2. Changes of body weight by ND treatment

\begin{tabular}{|c|c|c|c|c|c|c|c|c|c|c|c|c|c|c|}
\hline \multirow{2}{*}{$\begin{array}{c}\text { Treatment } \\
\text { period }\end{array}$} & \multirow{2}{*}{ Exp. group } & \multicolumn{13}{|c|}{ Body weight (g) } \\
\hline & & $0 \mathrm{wk}$ & $1 \mathrm{wk}$ & $2 \mathrm{wk}$ & $3 \mathrm{wk}$ & $4 \mathrm{wk}$ & $5 \mathrm{wk}$ & $6 \mathrm{wk}$ & $7 \mathrm{wk}$ & $8 \mathrm{wk}$ & $9 \mathrm{wk}$ & $10 \mathrm{wk}$ & $11 \mathrm{wk}$ & $12 \mathrm{wk}$ \\
\hline \multirow[t]{3}{*}{2 weeks } & Control (oil) & $156.7 \pm 1.45$ & $208.0 \pm 2.52$ & $269.8 \pm 4.90$ & - & - & - & - & - & - & - & - & - & - \\
\hline & Low (2 mg) & $156.9 \pm 1.40$ & $214.9 \pm 4.53$ & $271.1 \pm 4.65$ & - & - & - & - & - & - & - & - & - & - \\
\hline & High (10 mg) & $160.2 \pm 0.64$ & $227.6 \pm 2.18^{\mathrm{a}}$ & $286.0 \pm 5.44$ & - & - & - & - & - & - & - & - & - & - \\
\hline \multirow[t]{3}{*}{12 weeks } & Control (oil) & $162.0 \pm 1.23$ & $219.0 \pm 4.05$ & $277.9 \pm 4.81$ & $323.6 \pm 8.72$ & $352.9 \pm 11.34$ & $393.4 \pm 12.05$ & $408.9 \pm 12.81$ & $428.9 \pm 13.36$ & $445.2 \pm 15.05$ & $464.7 \pm 15.30$ & $479.6 \pm 16.44$ & $492.3 \pm 17.04$ & $502.6 \pm 17.48$ \\
\hline & Low (2 mg) & $163.5 \pm 3.22$ & $222.4 \pm 4.79$ & $281.2 \pm 7.49$ & $326.2 \pm 8.75$ & $357.8 \pm 10.23$ & $388.3 \pm 12.10$ & $409.2 \pm 13.99$ & $429.2 \pm 15.40$ & $447.3 \pm 15.59$ & $464.0 \pm 17.95$ & $480.9 \pm 20.18$ & $478.4 \pm 19.12$ & $489.6 \pm 22.01$ \\
\hline & High (10 mg) & $168.3 \pm 2.51$ & $230.4 \pm 4.18$ & $284.5 \pm 9.81$ & $332.0 \pm 13.68$ & $356.2 \pm 15.28$ & $385.2 \pm 18.03$ & $394.7 \pm 18.76$ & $402.3 \pm 19.92$ & $409.1 \pm 20.76$ & $412.0 \pm 20.67$ & $420.5 \pm 21.92$ & $422.9 \pm 22.37^{\mathrm{a}}$ & $429.3 \pm 24.05^{\mathrm{a}}$ \\
\hline
\end{tabular}

$\mathrm{ND}$, nandrolone decanoate; wk, the week of treatment.

a Significant to control and low. 
obtained from the relative standard curve method.

\section{Protein isolation and western blotting analysis}

About $10 \mathrm{mg}$ of testis was homogenized in $600 \mu \mathrm{L}$ of lysis buffer (ProPrep protein extraction solution, iNtRON Biotech, Sungnam, Korea) using a Polytron homogenizer (Fisher Scientific, USA), followed by incubation at $-20^{\circ} \mathrm{C}$ for $30 \mathrm{~min}$. Then a centrifugation at $166,096 \times \mathrm{g}\left(4^{\circ} \mathrm{C}\right)$ for $10 \mathrm{~min}$ was performed to collect protein supernatant, and the extracted protein was kept in $-80^{\circ} \mathrm{C}$ until used for western blotting analysis. The protein concentration was determined by the Bradford method (BioRad Laboratories, USA), with bovine serum albumin (BSA) as standard.

For western blotting analysis, the fractionated protein on $12 \%$ SDS-PAGE polyacrylamide gel (Invitrogen, USA) was transferred to a nitrocellulose membrane, followed by rinsing in Tris-buffered saline (TBS) with Tween (TBST; 0.2 M Tris, 1.37 M NaCl, $0.05 \%$ Tween-20) for a couple of times. The membrane was incubated in TBST with $1 \%$ BSA (Sigma, St Louis, MO, USA) for $1 \mathrm{~h}$ at room temperature to block nonspecific binding. Adequate concentrations of primary antibodies were determined by a series of preliminary studies. We used dilution of 1:1,000 for StAR (polyclonal rabbit anti-StAR; a precious gift from Dr. Douglas Stocco, Texas Tech University, Lubbock, TX, USA), 1:2,000 for CYP11A1 (AB1244; Chemicon International, Temecula, CA, USA), 1:1,000 for CYP17 (polyclonal rabbit anti-CYP17; a generous gift from Dr. Anita Payne, Stanford University, Stanford, CA, USA), 1:1,000 for HSD3B1 (polyclonal rabbit anti-HSD3B1; a benevolent gift from Dr. Ian Mason, University of Edinburgh, Edinburgh, UK), and 1:500 for CYP19 (polyclonal rabbit anti-CYP19; a generous gift from Dr. Nobuhiro Harada, Fujita Health University, Japan). The primary antibody was applied to the membrane for overnight at $4^{\circ} \mathrm{C}$. After washing in TBST for 3 times, the membrane was incubated with goat anti-rabbit HRP-conjugated IgG (Santa Cruz Biotechnology, Inc., Santa Cruz, CA, USA) diluted at 1:500 in TBST at room temperature for $1 \mathrm{~h}$. The excess secondary antibody on the membrane was removed by washing in TBST for 5 times. Then, the membrane was exposed to the enhanced chemiluminescence detection system (Amersham Biosciences, Pittsburgh, PA, USA) to obtain blotting results. The results on the X-ray film were analyzed by image analysis software, Image J, released from the $\mathrm{Na}$ tional Institutes of Health (Bethesda, MD, USA; http://rsb.info. nih.gov/ij/download.html). Beta-actin (ACTB, SC-47778; Santa Cruz Biotechnology, Inc., USA) was used for an internal control.

\section{H\&E staining and immunohistochemical analysis}

The testis fixed in Bouin's solution for overnight at room temperature was transferred into $70 \% \mathrm{EtOH}$. The testis was dehydrated in a series of ethanol (90\%, 95\%, and $100 \%)$, cleared in xylene, and then infiltrated with paraffin. Paraffin-embedding testis was sectioned at thickness of $4 \mu \mathrm{m}$ and placed on charged slide (Fisher Scientific, USA). For H\&E staining, tissue section was deparaffinized in xylene and rehydrated in a series of ethanol and water. Then, the section was stained with hematoxylin (YD Diagnostics, Yongin, Korea) for $1 \mathrm{~min}$ at room temperature. After washing in running water, the section was immersed in eosin solution (Merck, Darmstadt, Germany) for $1 \mathrm{~min}$, followed by direct dehydration in a series of ethanol and clearing with xylene. Mounted section was examined under light microscopy for histological evaluation. Digitalized image was captured by Olympus-CoolSNAP cf color/OL camera (Olympus America, Melville, NY, USA) using RSImage version 1.1 software (Roper Scientific, Duluth, GA, USA). The image was processed in Adobe PhotoShop CS5 software (Adobe Systems, San Jose, CA, USA).

For immunohistochemical study, tissue section was first deparaffinized in xylene and then rehydrated in a series of ethanol. The section was microwaved in $0.01 \mathrm{M}$ citrate buffer, pH 6.0 for $10 \mathrm{~min}$ for antigen retrieval. Endogenous peroxidase was inactivated in $0.3 \% \mathrm{H}_{2} \mathrm{O}_{2} /$ methanol for $15 \mathrm{~min}$ at room temperature. The section was exposed to $5 \%$ normal goat serum (Chemicon International, USA) for $30 \mathrm{~min}$ at room temperature to block nonspecific binding of the primary antibody. Diluted primary antibody was applied to the section in a humidified chamber at $4^{\circ} \mathrm{C}$ for overnight. Proper concentrations of primary antibodies for immunohistochemistry were determined by a series of multiple preliminary trials. Dilutions of the primary antibodies used at the present study were as following; 1:200 for StAR, 1:500 for CYP11A1, 1:200 for CYP17, 1:500 for HSD3B1, and 1:100 for CYP19. The primary antibodies used for western blotting analysis were employed for immunohistochemical analysis. Excess primary antibody was washed off in phosphate-buffered saline (PBS). Then, the section was incubated with biotinylated goat anti-rabbit IgG secondary antibody (DAKO Corporation, Carpinteria, CA, USA) of 1:100 dilution for $1 \mathrm{~h}$ at room temperature. Unbound IgG was removed by PBS washing, and elite avidin-biotin peroxidase (Vector Laboratories, Burlingame, CA, USA) was placed on the sections for $30 \mathrm{~min}$ at room temperature. After washing in PBS for three times, the section was employed with a mixture of 3,3'-diaminobenzidine (Sigma, USA), $0.05 \mathrm{M}$ Tris- $\mathrm{HCl}$ buffer, and $5 \%$ hydrogen peroxide to detect the peroxidase. The section was then counterstained with hematoxylin. Immuno-reactivity on the section was evaluated with digitalized images captured with OlympusCoolSNAP cf color/OL camera using RSImage version 1.1 software. The image was slightly processed in Adobe PhotoShop software.

\section{Data analysis and presentation}

All data were presented as means \pm standard errors. Statistical 
comparison of means was carried out among experimental groups within each treatment period by using one-way analysis of variance followed by Duncan's post hoc test. In all cases, results were considered significant if $\mathrm{p}$ value was lower than 0.05 .

For real-time PCR analysis, we quadruplicated the RT reaction and real-time PCR for each sample to obtain a mean. The mean value normalized to the quantitative value of Ppia was used for statistical comparison. Expressional level of target transcript was expressed relative to Ppia as an arbitrary unit. For western blotting analysis, each sample was triplicated, and the mean value normalized to the value of ACTB was used for statistical comparison. Abundance of protein was expressed relative to normalized value of control group as arbitrary units.

\section{RESULTS}

Changes of body and serum testosterone concentration A transient and unexpected increase of body weight was observed with a high-dose ND treatment at the 1st week of 2-weeks ND treatment experiment, even though there was no significant difference among experimental groups at the second week (Table 2). There was no significant change of body weight by ND treatment at a low-dose ND treatment for 12 weeks (Table 2). However, a high-dose ND treatment for 12 weeks resulted in significant decreases of body weight at the 11th and 12th week (Table 2).

The concentration of serum testosterone was significantly decreased by a low-dose ND treatment for 2 weeks, compared with that of the control (Figure 1). A further reduction of serum testosterone concentration was detected with a high-dose ND treatment for 2 weeks (Figure 1). The serum testosterone level of a low-dose ND treatment group for 12 weeks was

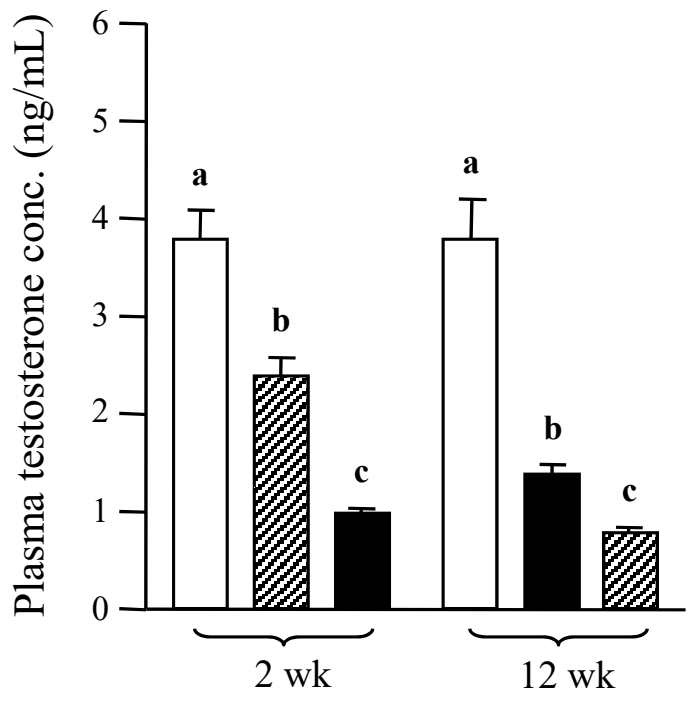

Experimental group

Figure 1. Change of serum testosterone concentration with the treatment of nandrolone decanoate (ND). The treatment of ND was performed for 2 weeks (2 wk) or 12 weeks (12 wk) at a low-dose (Low, $2 \mathrm{mg} \mathrm{ND/kg}$ body weight [BW]/ wk) or a high-dose (High, $10 \mathrm{mg} \mathrm{ND/kg} \mathrm{BW/wk)}$. Different letters indicate significant differences among experimental groups $(p<0.05)$. $\square$, control (peanut oil); $\square$, a low dose-treated group (2 mg ND/kg BW/wk); $\mathbf{n}$, a high dose-treated group (10 mg ND/kg BW/wk).

significantly lower than that of the control (Figure 1). An additional decrease of serum testosterone level was detected with a high-dose ND treatment for 12 weeks (Figure 1).

Histological changes in the testis and expressional changes of Star transcript and protein

The ND treatment resulted in considerable histological changes in the testis (Figure 2). Notable abnormalities were the decline of Leydig cell population within the interstitial compartment

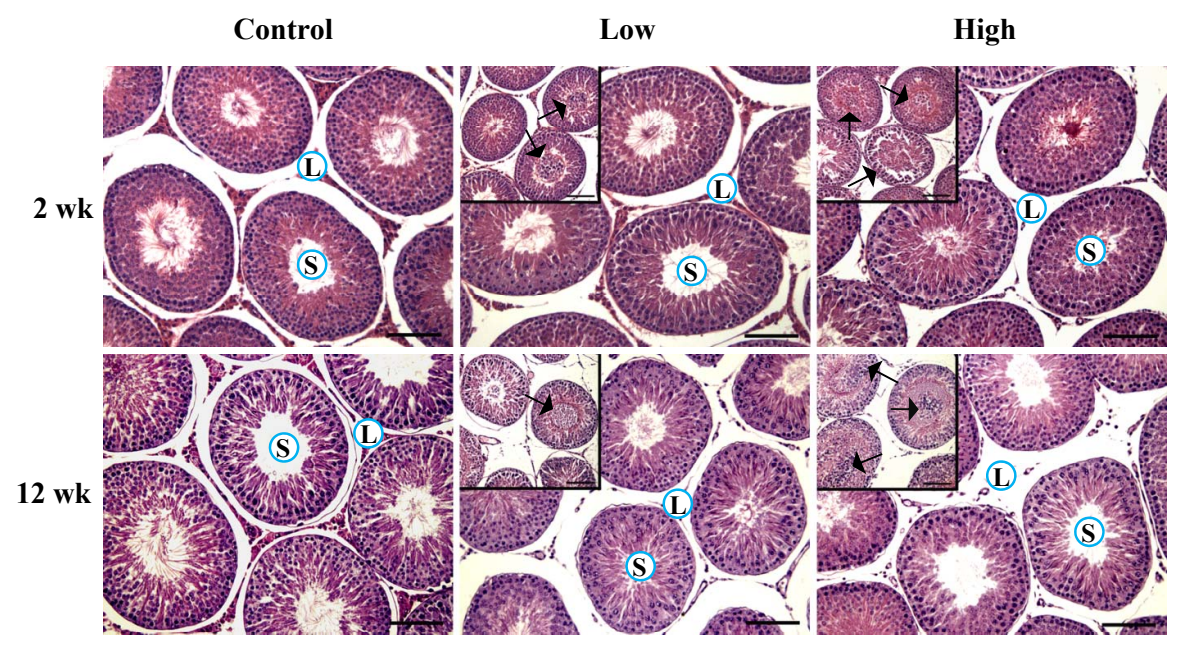

Figure 2. Histological comparison of the testes treated with nandrolone decanoate (ND). The reduction of Leydig cell number in the interstitial compartment and the sloughing of germ cells (arrows in inserts) within seminiferous tubules (S) were observed with a low-dose (Low, 2 mg ND/kg body weight/wk) or a high-dose (High, $10 \mathrm{mg}$ $\mathrm{ND} / \mathrm{kg}$ body weight/wk) treatments for 2 weeks ( 2 wk) or 12 weeks (12 wk). Bars $=10 \mu \mathrm{m}$. Bars in inserts $=5 \mu \mathrm{m}$. 
and the sloughing of germ cells within the seminiferous tubules (Figure 2). Even though visible reduction of Leydig cell number was not observed by a low-dose ND treatment for 2 weeks, a high-dose ND treatment for 2 weeks caused a notable decrease of Leydig cell population in the interstitial compartment (Figure 2). A diminishing number of Leydig cell was even apparent in ND treatment groups for 12 week (Figure 2). The Leydig cell in the interstitial compartment was hardly detectable in the testis exposed to a low-dose ND treatment for 12 weeks and was mostly disappeared with a high-dose ND treatment for 12 weeks (Figure 2). In addition, the administration of ND caused the sloughing of germ cells in the seminiferous tubules of the testis (Figure 2). The phenomenon was more frequent and severe in the higher dose and longer treatment groups (Figure 2 and personal observation).

The transcript level of testicular Star was not changed by a low-dose ND treatment for 2 weeks but was significantly reduced by a high-dose ND treatment for 2 weeks (Figure 3A). Significant decreases of Star mRNA levels were detected with ND treatments at a low-dose and a high-dose for 12 weeks, even though there was no difference on the transcript level of Star between two 12-week ND treatment groups (Figure $3 A)$. The ND treatment at a low-dose for 2 weeks didn't give an influence on the protein level of StAR, but a significant reduction of testicular StAR protein level was observed with a high-dose ND treatment for 2 weeks (Figure 3B). The level of StAR was significantly decreased by a low-dose ND treatment for 12 weeks, and a further reduction of StAR protein level was observed in a high-dose ND treatment group for 12 weeks (Figure 3B). Immunohistochemical analysis revealed that the StAR was exclusively localized in Leydig cell of the interstitial compartment, even though non-specific immunostaining of STAR was often found within the seminiferous tubules, especially acrosomal regions of spermatozoa (Figure 3C, Table 3). In ND treatment groups for 2 weeks, detectable reduction of StAR immunostaining was only found in a highdose treatment group (Figure 3C, Table 3). The ND treatment for 12 weeks resulted in the absence of StAR-positive cell within the interstitial compartment (Figure 3C, Table 3).
A

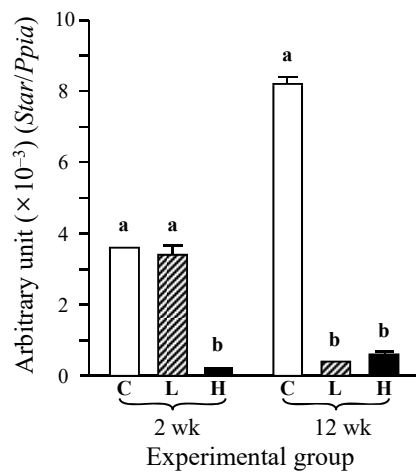

C

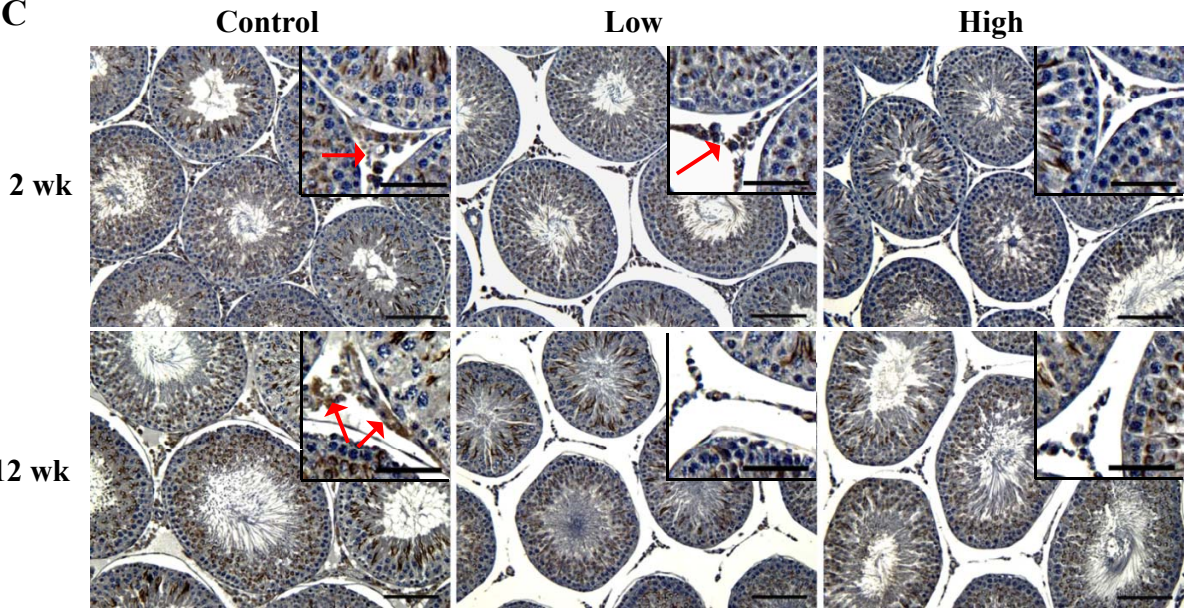

B

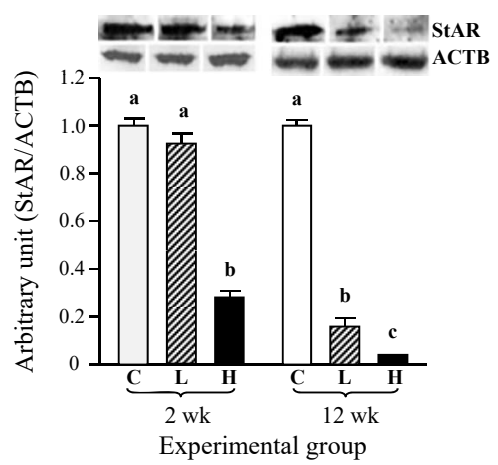

Figure 3. Effects of nandrolone decanoate (ND) treatment on the expression of testicular steroidogenic acute regulatory protein (Star). The treatment of ND was performed for 2 weeks ( 2 wk) or 12 weeks (12 wk) at a low-dose (Low, 2 mg ND/kg body weight/wk) or a high-dose (High, $10 \mathrm{mg} \mathrm{ND/kg} \mathrm{body} \mathrm{weight/wk).} \mathrm{The} \mathrm{ND} \mathrm{treatment} \mathrm{resulted}$ in changes of Star transcript (A) and protein (B) levels. Different letters above bars indicate significant differences among experimental groups ( $p<0.05)$. Ppia, cyclophilin A. $\square$, control (peanut oil); $\square$, a low-dose-treated group; $\mathbf{\square}$, a high-dose-treated group. ACTB, $\beta$-actin. (C) Immunohistochemical localization of StAR in the testis. The Leydig cells (arrows) were strongly immune-stained for StAR. Bars $=10 \mu \mathrm{m}$ and bars in inserts $=5 \mu \mathrm{m}$. 
Table 3. Summary of immunohistochemical analysis

\begin{tabular}{|c|c|c|c|c|c|c|c|c|c|c|c|c|c|c|c|c|c|c|}
\hline \multirow{3}{*}{ Molecule } & \multicolumn{9}{|c|}{$2 w^{1)}$} & \multicolumn{9}{|c|}{$12 \mathrm{wk}$} \\
\hline & \multicolumn{3}{|c|}{ Leydig cell } & \multicolumn{3}{|c|}{ Sertoli cell } & \multicolumn{3}{|c|}{ Germ cell } & \multicolumn{3}{|c|}{ Leydig cell } & \multicolumn{3}{|c|}{ Sertoli cell } & \multicolumn{3}{|c|}{ Germ cell } \\
\hline & $\mathrm{C}^{2)}$ & $\mathrm{L}$ & $\mathrm{H}$ & $\mathrm{C}$ & $\mathrm{L}$ & $\mathrm{H}$ & C & L & H & $\mathrm{C}$ & L & $\mathrm{H}$ & $C$ & $\mathrm{~L}$ & $\mathrm{H}$ & C & L & $\mathrm{H}$ \\
\hline StAR & + & + & $+/-a$ & - & - & - & - & - & - & + & - & - & - & - & - & - & - & - \\
\hline CYP11A1 & + & + & - & - & - & - & - & - & - & + & - & - & - & - & - & - & - & - \\
\hline CYP17 & + & + & - & - & - & - & - & - & - & + & - & - & - & - & - & - & - & - \\
\hline HSD3B1 & + & + & + & - & - & - & - & - & - & + & $+/^{\mathrm{a}}$ & - & - & - & - & - & - & - \\
\hline CYP19 & + & $+/-$ & - & $+/-$ & $+/-$ & $+/-$ & $+/^{\mathrm{a}}$ & $+/^{\mathrm{a}}$ & $+/^{\mathrm{a}}$ & + & - & - & $+/$ & $+/-$ & $+/-$ & $+/^{\mathrm{a}}$ & $+/^{\mathrm{a}}$ & $+/^{\mathrm{a}}$ \\
\hline
\end{tabular}

StAR, steroidogenic acute regulatory protein; CYP11A1, cytochrome P450 side chain cleavage; CYP17, cytochrome P450 17a-hydroxylase; HSD3B1, 3ß-hydroxysteroid dehydrogenase type 1; CYP19, cytochrome P450 aromatase.

1) 2 wk, 2 weeks-treatment; 12 wk, 12 weeks-treatment.

2) $\mathrm{C}$, control; L, low-dose of ND -treated (2 mg/kg body weight/wk); H, high-dose of ND-treated (10 mg/kg body weight/wk).

${ }^{3)}+$, positive; +l-, weakly positive; -, negative.

${ }^{a}$ Not all cells positive.

\section{Expressional changes of Cyp11a1 and Cyp17 transcripts} and proteins

The level of Cyp11a1 mRNA was significantly decreased by a low-dose ND treatment for 2 weeks, and a further reduction of Cyp11al transcript level was observed in a high-dose treatment group for 2 weeks (Figure 4A). The ND treatment for 12 weeks resulted in a significant reduction of Cyp11a1 transcript level, even though there was no statistical difference on
A

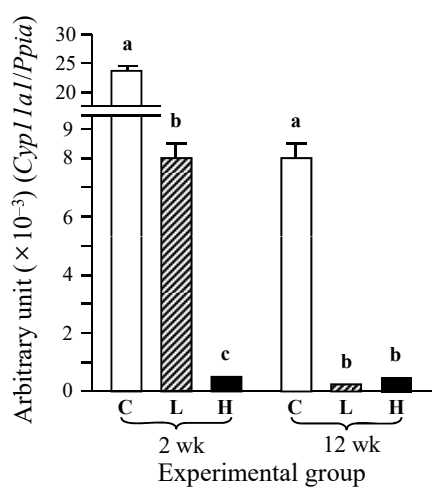

C

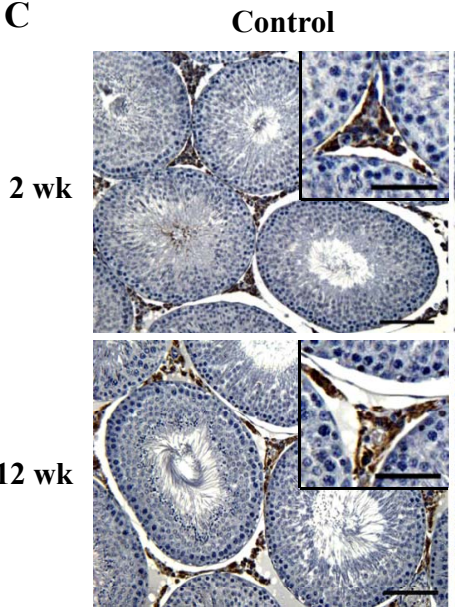

B

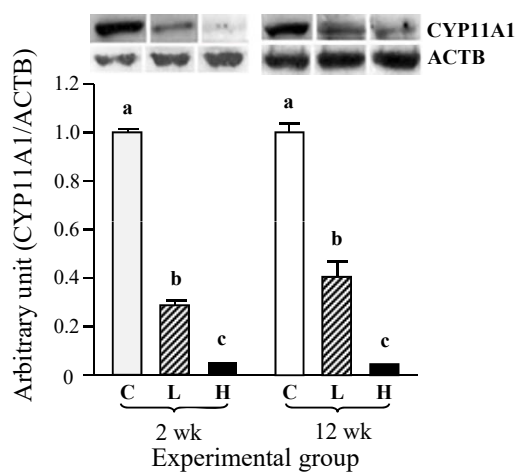

Low

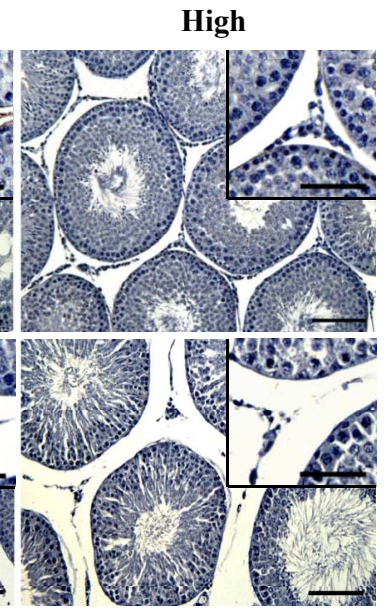

Figure 4. Effects of nandrolone decanoate (ND) treatment on the expression of testicular cytochrome P450 side chain cleavage (Cyp11a1). The treatment of ND was performed for 2 weeks (2 wk) or 12 weeks (12 wk) at a low-dose (Low, 2 mg ND/kg body weight/wk) or a high-dose (High, 10 mg ND/kg body weight/wk). The ND treatment resulted in changes of Cyp11a1 transcript (A) and protein (B) levels. Different letters above bars indicate significant differences among experimental groups (p<0.05). Ppia, cyclophilin A. $\square$, control (peanut oil); $\bigotimes$, a low-dose-treated group; $\mathbf{a}$, a high-dose-treated group. ACTB, $\beta$-actin. (C) Immunohistochemical localization of CYP11A1 in the testis. The immuno-reactivity of CYP11A1 was visible in the Leydig cells. Bars $=10 \mu \mathrm{m}$ and bars in inserts $=5 \mu \mathrm{m}$. 
Cyp11a1 transcript level between two ND-treated groups for 12 weeks (Figure 4A). At protein level, a low-dose ND treatment for 2 weeks caused a significant decrease of CYP11A1 amount (Figure 4B). An additional reduction of CYP11A1 level was detected with a high-dose ND treatment for 2 weeks (Figure 4B). The CYP11A1 level was also significantly decreased by a low-dose ND treatment for 12 weeks, and a further reduction of CYP11A1 level was found in a high-dose ND treatment group for 12 weeks (Figure 4B). Immunohistochemical analysis showed the exclusive localization of CYP11A1 in Leydig cell (Figure 4C, Table 3). The strong immunostaining of CYP11A1 in Leydig cell was observed in a low-dose ND treatment group for 2 weeks, but the positive staining of CYP11A1 was not detectable in a high-dose ND treatment group for 2 weeks (Figure 4C, Table 3). No immunostaining of CYP11A1 was found within the interstitial compartment of the testis treated with ND for 12 weeks (Figure 4C, Table 3).

The expressional change of testicular Cyp17 by ND treatment is shown in Figure 5. The transcript level of Cyp17 was not affected by a low-dose ND treatment for 2 weeks, while a significant decrease of Cyp17 mRNA level was observed with a high-dose ND treatment for 2 weeks (Figure 5A). The ND treatments at low- and high-doses for 12 weeks also resulted in considerable decreases of Cyp17 mRNA levels (Figure 5A). The protein level of CYP17 was significantly decreased by a low-dose ND treatment for 2 weeks, and an additional reduction of CYP17 amount was observed with a high-dose ND treatment for 2 weeks (Figure 5B). Similar findings were detected with the ND treatment for 12 weeks, i.e., a significant decrease of CYP17 level by a low-dose ND treatment and a further drop of CYP17 amount by a high-dose ND treatment (Figure 5B). The CYP17 in the testis was exclusively localized in Leydig cell of the interstitial compartment (Figure 5C, Table 3). The immunostaining of CYP17 in Leydig cell was clearly visible in the control group and a low-dose ND treatment group for 2 weeks, but the CYP17-immunostained Leydig cell was not observed in a high-dose ND treatment group for 2 weeks (Figure 5C, Table 3). The ND treatment of 12 weeks resulted in the complete disappearance of Leydig cell, positively stain-
A

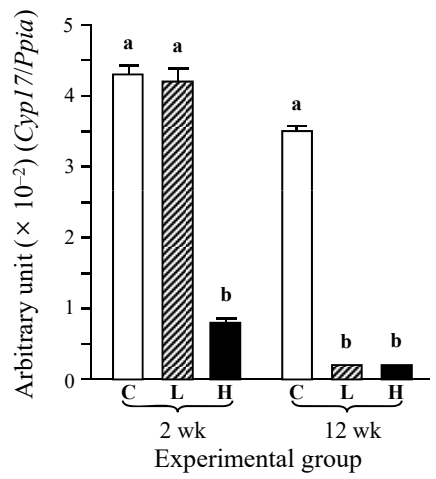

B

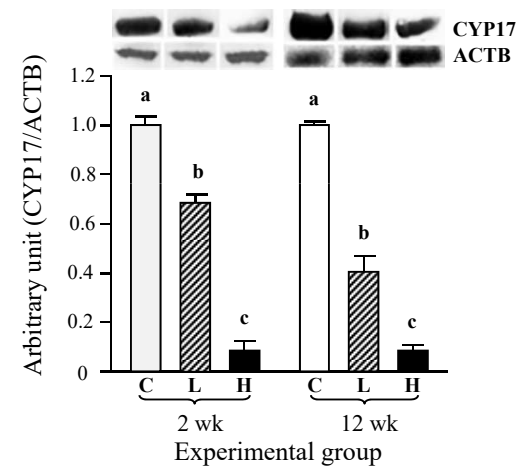

\section{C}

Control

\section{.}

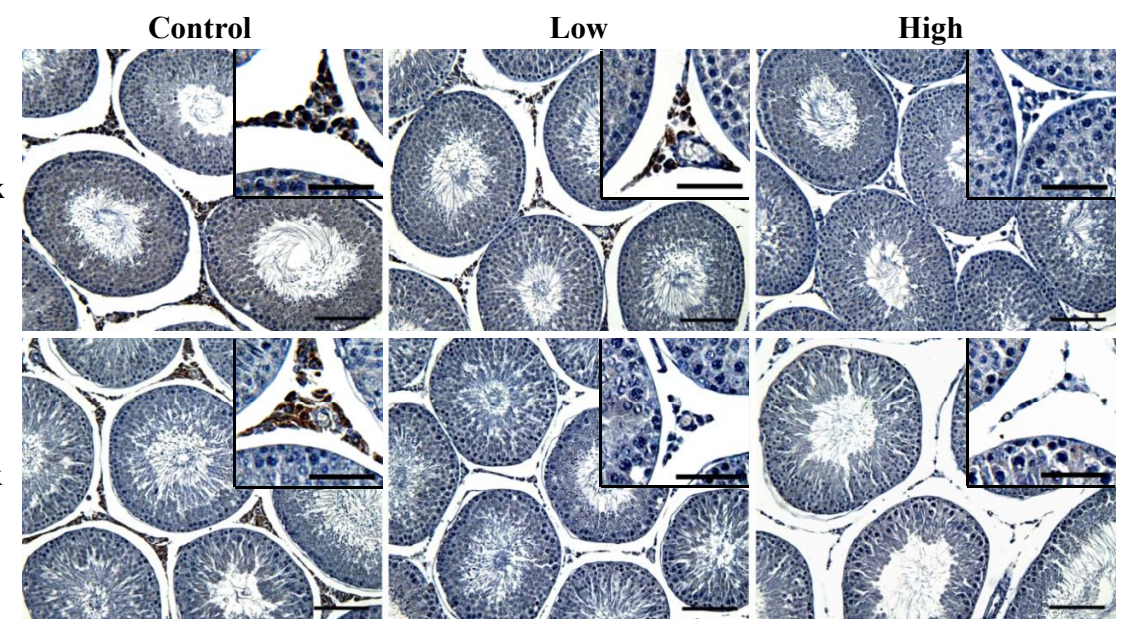

Figure 5. Effects of nandrolone decanoate (ND) treatment on the expression of testicular cytochrome P450 17a-hydroxylase (Cyp17). The treatment of ND was performed for 2 weeks ( 2 wk) or 12 weeks (12 wk) at a low-dose (Low, $2 \mathrm{mg} \mathrm{ND/kg} \mathrm{body} \mathrm{weight/wk)} \mathrm{or} \mathrm{a} \mathrm{high-dose} \mathrm{(High,} 10 \mathrm{mg} \mathrm{ND/kg} \mathrm{body} \mathrm{weight/wk).} \mathrm{The} \mathrm{ND} \mathrm{treatment} \mathrm{resulted}$ in changes of Cyp17 transcript (A) and protein (B) levels. Different letters above bars indicate significant differences among experimental groups ( $p<0.05)$. Ppia, cyclophilin A. $\square$, control (peanut oil); $\square$, a low-dose-treated group; $\mathbf{m}$, a high-dose-treated group. ACTB, $\beta$-actin. (C) Immunohistochemical localization of CYP17 in the testis. Positive immuno-staining of CYP17 was exclusively localized in the Leydig cells. Bars $=10 \mu \mathrm{m}$ and bars in inserts $=5 \mu \mathrm{m}$. 
ing for CYP17 (Figure 5C, Table 3).

\section{Expressional changes of $H s d 3 b 1$ and $C y p 19$ transcripts and proteins}

The ND treatment for 2 weeks didn't cause the change of $H s d 3 b 1$ transcript level (Figure 6A). However, the level of $H s d 3 b 1$ transcript was significantly decreased by a low-dose ND treatment for 12 weeks (Figure 6A). An additional significant reduction of $H s d 3 b 1 \mathrm{mRNA}$ level was observed with a high-dose ND treatment for 12 weeks (Figure 6A). A low-dose ND treatment for 2 weeks didn't influence on the HSD3B1 protein level, even though a significant decrease of HSD3B1 amount was detected with a high-dose ND treatment for 2 weeks (Figure 6B). The ND treatments at two doses for 12 weeks induced significant decreases of testicular HSD3B1 levels, although there was no remarkable difference on the level of HSD3B1 between a low-dose and a high-dose ND treatment groups for 12 weeks (Figure 6B). The immuno-localization of HSD3B1 in the testis was restricted into Leydig cell (Figure 6C, Table 3). The staining intensity of HSD3B1 was not visibly changed by the ND treatment for 2 weeks, even though the reduction of HSD3B1-immunostained Leydig cell number was apparent in a high-dose ND treatment for 2 weeks (Figure 6C, Table 3). The reduced intensity of HSD3B1-immunostaining in Leydig cell was observed with a low-dose ND treatment for 12 weeks (Figure 6C, Table 3). Not all Leydig cell of a low-dose ND treatment group for 12 weeks was immunostained (Figure 6C, Table 3). There was no observable HSD3B1-immunostained Leydig cell in the testis treated with a high-dose ND for 12 weeks (Figure 6C, Table 3).

The effect of ND treatment on the expression of testicular Cyp19 is shown in Figure 6. The mRNA level of Cyp19 was not changed by the ND treatment for 2 weeks (Figure 7A). However, a significant decrease of Cyp19 transcript level was observed with a low-dose ND treatment for 12 weeks, even though the Cyp19 mRNA level was not further altered by a high-dose ND treatment for 12 weeks (Figure 7A). The CYP19 protein level was not influenced by the ND treatment for 2
A

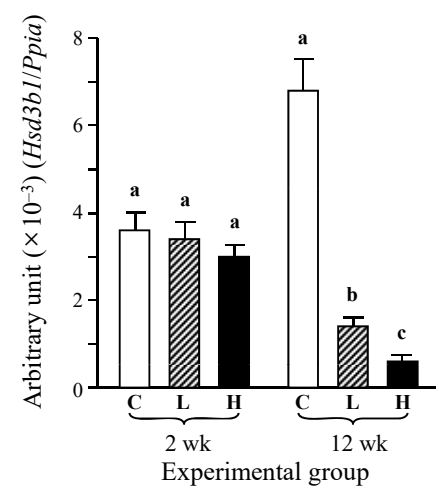

B

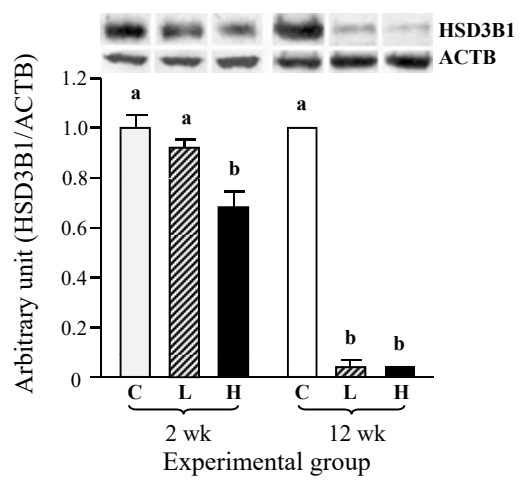

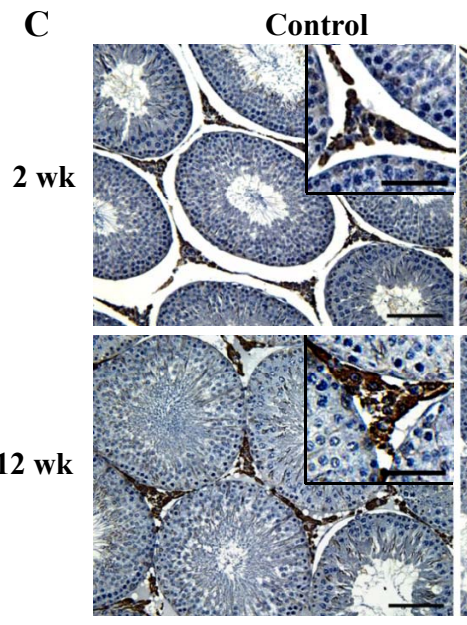

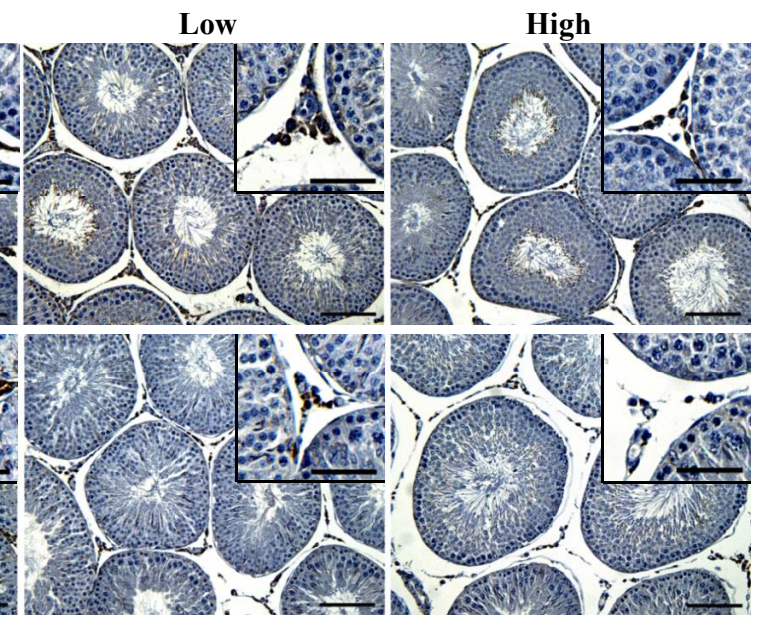

Figure 6. Effects of nandrolone decanoate (ND) treatment on the expression of testicular 3-beta-hydroxysteroid dehydrogenase/delta-5-delta-4 isomerase type I (Hsd3b1). The treatment of ND was performed for 2 weeks (2 wk) or 12 weeks (12 wk) at a low-dose (Low, 2 mg ND/kg body weight/wk) or a high-dose (High, 10 mg ND/kg body weight/wk). The ND treatment resulted in changes of Hsd3b1 transcript (A) and protein (B) levels. Different letters above bars indicate significant differences among experimental groups $(p<0.05)$. Ppia, cyclophilin A. $\square$, control (peanut oil); $\square$, a low-dose-treated group; $\mathbf{\square}$, a high-dose-treated group. ACTB, $\beta$-actin. (C) Immunohistochemical localization of HSD3B1 in the testis. Strongly positive immuno-staining of HSD3B1 was observed only in the Leydig cells. Bars $=10 \mu \mathrm{m}$ and bars in inserts $=5 \mu \mathrm{m}$. 
A

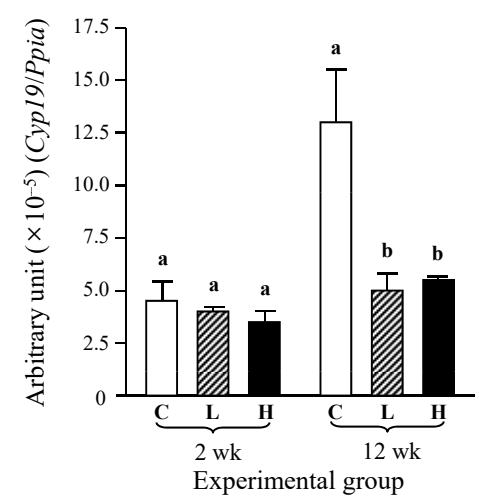

B

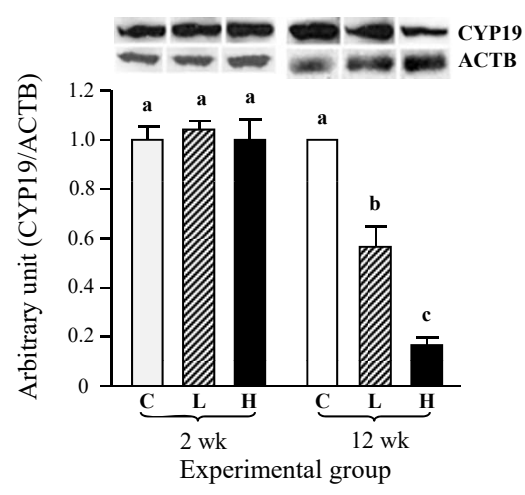

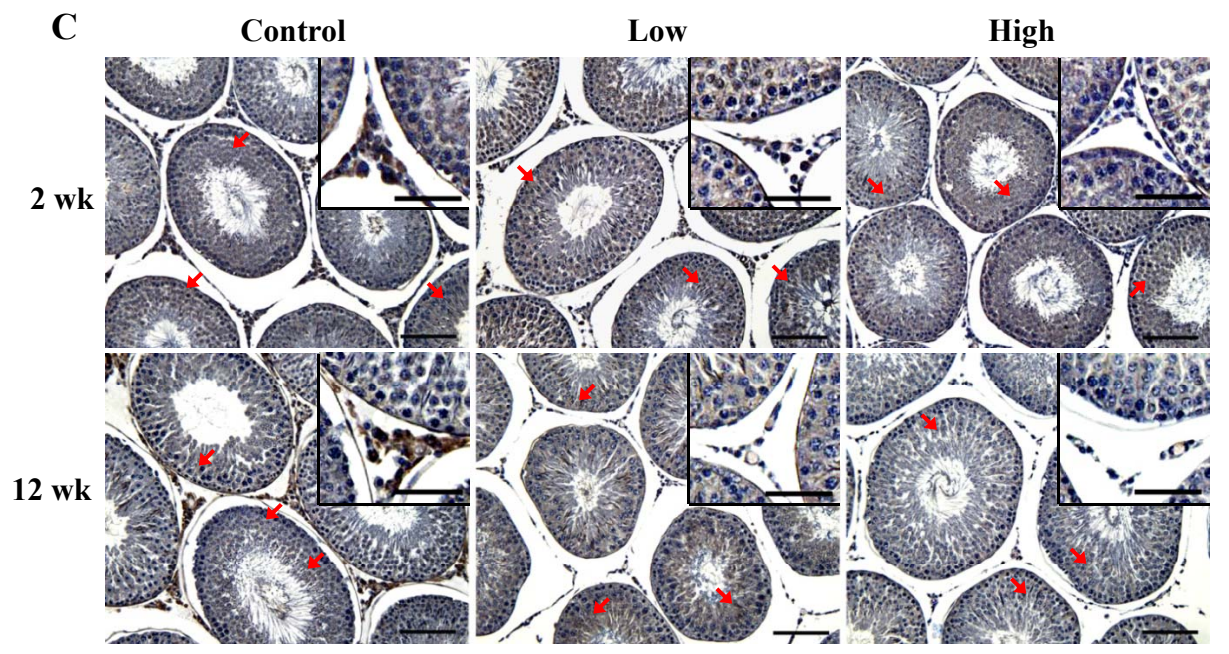

Figure 7. Effects of nandrolone decanoate (ND) treatment on the expression of testicular cytochrome P450 aromatase (Cyp19). The treatment of ND was performed for 2 weeks ( 2 wk) or 12 weeks (12 wk) at a low-dose (Low, $2 \mathrm{mg} \mathrm{ND} / \mathrm{kg}$ body weight/wk) or a high-dose (High, $10 \mathrm{mg} \mathrm{ND/kg} \mathrm{body} \mathrm{weight/wk).} \mathrm{The} \mathrm{ND} \mathrm{treatment} \mathrm{resulted} \mathrm{in}$ changes of Cyp19 transcript (A) and protein (B) levels. Different letters above bars indicate significant differences among experimental groups ( $p<0.05)$. Ppia, cyclophilin A. $\square$, control (peanut oil); $\square$, a low-dose-treated group; $\mathbf{m}$, a high-dose-treated group. ACTB, $\beta$-actin. (C) Immunohistochemical localization of CYP19 in the testis. Strongly positive immuno-staining of CYP19 was detected in the Leydig cells, and certain germ cells, spermatozoa, and Sertoli cells in seminiferous tubules were also immunepositive for CYP19 (arrows). Bars $=10 \mu \mathrm{m}$ and bars in inserts $=5 \mu \mathrm{m}$.

weeks, while a significant decrease of testicular CYP19 amount was detected in a low-dose ND treatment group for 12 weeks (Figure 7B). An additional drop of CYP19 protein level was observed with a high-dose ND treatment for 12 weeks (Figure 7B). Immunohistochemical analysis showed positive immunostaining of CYP19 in the several testicular cell types, including Leydig, Sertoli, and certain types of germ cells (Figure 7C, Table 3). The intensity of CYP19 immunostaining became notably weaken in Leydig cell of the testis treated with a lowdose ND for 2 weeks, while the immunoreactivity of CYP19 in Sertoli and germ cells was not visibly changed with a lowdose ND treatment for 2 weeks (Figure 7C, Table 3). The ND treatment at a high-dose for 2 weeks caused the disappearance of CYP19 immuno-reactivity within the interstitial compartment (Figure 7C, Table 3). However, there was no remarkable change of CYP19 immuno-intensity in Sertoli and germ cells by a high-dose ND treatment for 2 weeks (Figure 7C, Table
3). The ND treatment for 12 weeks resulted in no immunostaining of CYP19 within the interstitial compartment of the testis (Figure 7C, Table 3). But, the intensity of CYP19 immunostaining in Sertoli and germ cells was not affected by ND treatment for 12 weeks (Figure 7C, Table 3).

\section{DISCUSSION}

The effect of ND administration on the expression of testicular steroidogenic enzymes has been reported from previous researches. However, a number of target enzymes examined are limited, and a comparative investigation of the effect of ND treatment at different doses and for different periods on the expression of several steroidogenic enzymes in the testis has not been performed yet. The present study has been conducted to simultaneously evaluate the impact of ND on the expression of key steroidogenic enzymes in pubertal rat testis 
according to the dose and period of the treatment. In brief summary of our findings, the treatment of ND at a low dose for a short period is sufficient to affect normal expression of testicular steroidogenic enzymes, and the deleterious effects of ND on the testis have become more convinced with longer treatment and at higher dose treatment.

The administration of ND accompanies with a reduction of serum testosterone level and a decrease of body weight $[8,9]$. The relevant findings with ND treatment have been observed in the present research $[8,9]$. These results imply that ND treatment in the current study has been properly carried out and been effectively worked as in other previous researches $[8,9]$. Histological changes in the testis by ND administration have been reported from other researches. These include a depletion of Leydig cells [9] and detachment of germ and Sertoli cells from the basal layer within the seminiferous tubules [8]. The sloughing of germ cells and a depletion of Leydig cells have been also observed in the present study. In addition, the seminiferous tubules having the aggregate of detached germ and Sertoli cells within the lumen has been more frequent in a high-dose ND treatment group and longer ND treatment group (personal observations). Such degenerative changes in the testis are frequently associated with exposure to various environmental pollutants [15], thus suggesting the toxicity of $\mathrm{ND}$ on the male reproductive tract. The several sperm parameters, including concentration and motility of ejaculating sperm and numbers of spermatids and primary spermatocytes, are severely affected by ND treatment $[9,16]$. The present research has not assessed the quantitative changes of sperms and germ cells induced by ND. However, the alteration of such parameters could be indirectly postulated from the current histological findings, such as a decrease of testosterone production, depletion of Leydig cells, and sloughing of germ cell and Sertoli cell. Detailed morphological examination of ND-treated testis is suggested to determine the effect of ND on spermatogenesis and production of testicular spermatozoa.

A series of enzymatic reactions are required to synthesize testosterone and estrogen from cholesterol [1]. Our results showed that the treatment of $10 \mathrm{mg} \mathrm{ND} /$ week for 2 weeks was sufficient to significantly reduce both $\mathrm{mRNA}$ and protein levels of StAR. It is well documented that the expression of StAR in the testis is localized in Leydig cell [17]. Thus, it makes a sense that a decrease of Leydig cell population would result in the expressional decline of StAR. Indeed, a high-dose ND treatment, not a low-dose ND treatment, for 2 weeks caused visible reduction of Leydig cell number in the testis. In addition, even greater decline of StAR expression has been detected with a long-term ND administration. Moreover, immunohistological examination of StAR strongly supports the data of real-time PCR and western blotting analyses. Therefore, it is considered that expressional modulation of StAR by ND treatment is likely associated with the depletion of Leydig cell population in the testis. However, a recent publication has reported the modulation of testicular StAR protein level, not mRNA level, by the treatment of $10 \mathrm{mg} \mathrm{ND} /$ week for 6 weeks in fully mature mice [12]. The disagreement on expression of StAR by ND treatment between our and other's researches could be explained by the use of different age group. Because the testis of young adult is not fully developed and is thus more susceptible to exogenous substances than fully mature adult, it is speculated that even shorter treatment of ND at same amount could yield more severe and dramatic outcomes. The supplementary examination is required to determine the existence of differential effect of ND on the testis according to age.

A side chain of cholesterol imported into the mitochondria is cleaved by the action of CYP11A1 to produce pregnenolone. The stimulatory effect of nandrolone on CYP11A1 activity in human placental extract culture has been reported [18]. In the testis, Barone et al [12] have shown no expressional change of CYP11A1 in mRNA and protein levels after the treatment of $10 \mathrm{mg} \mathrm{ND} /$ week for 6 weeks, in spite of the atrophy of interstitial Leydig cell population. These findings are in disagreement with our data on CYP11A1, showing the first significant drop at transcript level among steroidogenic enzymes examined, even by $2 \mathrm{mg} \mathrm{ND}$ /week for 2 weeks. Like StAR, the existence of CYP11A1 in the testis is exclusively localized within the Leydig cell [17]. Thus, it is logic to suppose that the disappearance of Leydig cell population by ND treatment would result in expressional changes of molecule(s) existing in the interstitial compartment of the testis at transcript and protein levels. Therefore, it seems that expressional decreases of CYP11A1 at transcript and protein levels in the ND-treated testis are strongly associated with the reduction of Leydig cell number. In addition, to our knowledge, this is the first report that CYP11A1 is the earliest testicular steroidogenic enzyme exhibiting the response to ND treatment at transcript level. Moreover, it is proposed that a decrease of CYP11A1 protein level at a low-dose ND treatment for 2 weeks would contribute to a significant reduction of serum testosterone levels in part. Detailed examination is suggested to resolve the effect of ND on the transcriptional regulatory pathway of Cyp11a1 gene.

In the smooth endoplasmic reticulum of Leydig cell, pregnenolone derived from cholesterol is metabolized into progesterone by the action of HSD3B1. As most of steroidogenic enzymes in the testis, the existence of HSD3B1 within the interstitial compartment of the testis is restricted in Leydig cell $[17,19]$. A decrease of HSD3B1 expression and activity in the testis by ND treatment has been demonstrated from most of previous other researches [9-11]. In addition, a recent publication has reported that the treatment of $10 \mathrm{mg} \mathrm{ND} /$ week for 6 weeks causes the reduction of HSD3B1 protein level, but not $H s d 3 b 1$ mRNA level [12]. In the present research, significant decreases of $H s d 3 b 1$ transcript and protein levels were detected with 
ND treatment for 12 weeks, which is in agreement with histological findings of the depletion of Leydig cell. However, a significant reduction of HSD3B1 protein level, but not its transcript level, was also found in a high-dose ND treatment group for 2 weeks. Based on Barone et al's [12] and our data, such inconsistency between transcript level and protein level on $H s d 3 b 1$ expression implies the possibility of post-transcriptional regulation of $H s d 3 b 1$ expression by a high-dose ND treatment for 2 weeks. Additional researches are required to address the effect of ND on $H s d 3 b 1$ expression in the testis at the post-transcriptional level.

The conversion of progesterone into androstenedione and then testosterone in the testis requires a sequential action of two enzymes, CYP17 and HSD17B. The restricted localization of CYP17 within Leydig cell of the testis has been observed from a previous research [19], as well as our immunohistochemical results. The reduced expression of CYP17 in Leydig cell line has been induced by nandrolone treatment [20], similarly observed from our current study. But, it is interested to notice that a low-dose ND treatment for 2 weeks resulted in a significant decrease of CYP17 protein level, but not Cyp17 transcript level. In addition, the decrement of CYP17 protein level by a low-dose ND treatment for 12 weeks was not as huge as that of Cyp17 mRNA level, even though most of the interstitial components, including Leydig cell, in the testis were disappeared. These results strongly suggest an existence of post-transcriptional regulatory mechanism, which involves in differential expression of Cyp17 gene at different treatment period of a low-dose ND. In addition, it is presumed that a decreases of serum testosterone concentration by a low-dose $\mathrm{ND}$ treatment for 2 weeks is a consequence of reduced testicular CYP17 and CYP11A1 protein levels. Further researches are necessarily conducted to uncover the effect of a low-dose ND treatment on the expression of Cyp 17 gene at post-transcriptional level according to treatment period. In the present research, the effect of ND treatment on $H s d 17 b$ expression in the testis has not examined. Other researches have already shown a decrease of rat testicular Hsd17b1 transcript level [21] and a possibility of reduced testicular HSD17B activity [22] after the exposure to ND. Thus, it is prudently accepted that expression of $H s d 17 b 3$, the most prominent form of $H s d 17 b$ gene family involving in a conversion of androstenedione into testosterone in the testis, at transcript and protein levels would be decreased by a long-term ND treatment performed in the current research.

Testosterone in the testis is further metabolized into $17 \beta$ estradiol in the presence of CYP19. The testicular CYP19 is localized in several cell types, including Leydig cell, Sertoli cell, and certain types of germ cells [23], as also shown in immunohistochemical analysis of the present research. Unlike other steroidogenic enzymes, the ND treatment for 2 weeks didn't considerably affect the expression of the testicular Cyp19, even though both transcript and protein levels of Cyp19 were decreased by the ND treatment for 12 weeks. The existence of considerable amount of functional CYP19 in Sertoli cell and germ cells, compared with that in Leydig cell, has been demonstrated [24]. Accordingly, it seems that the reduction of Leydig cell population by the ND treatments for 2 weeks does not remarkably influence on overall transcript and protein amounts of testicular Cyp19. The quantitative decreases of testicular Cyp19 at transcript and protein levels by ND treatment for 12 weeks are in agreement with other's findings in stallion treated chronically with ND [9]. It is proposed that the reduction of transcript and protein levels of Cyp19 gene by a long-term ND treatment is mostly driven from the decline of Leydig cell population in the interstitial compartment of the testis because there was no histological remark showing the defective Sertoli cell and/or the arrest of spermatogenesis within the seminiferous tubules. However, it is also considered that a loss of spermatogenic cells by germ cell sloughing after a prolonged exposure to ND would partly influence on the expressional decrease of Cyp19 in the testis. In addition, it is noteworthy that a CYP19 level of a high-dose ND treated group for 12 weeks was significantly lower than that of a low-dose ND treated group, even though there was no significant difference on Cyp19 transcript level between two ND treatment groups for 12 weeks. This observation implies the existence of expressional regulatory mechanism of Cyp 19 gene by ND at post-transcriptional level, which should be determined by additional researches.

The present research clearly shows the suppressive effect of ND on the expression of steroidogenic enzymes in the testis, even though the responsiveness to ND would be different in the molecule to the dose and/or the duration of treatment. The first molecule displaying a significant decrease at transcript level to a low-dose ND treatment for 2 weeks was Cyp11a1, in spite of no meaningful change in other molecules. Interestingly, the ND treatment at a low-dose for 2 weeks resulted in the reduction of protein level of Cyp17, without affecting the transcript level. The ND administration at a high-dose for 2 weeks caused the declines of both transcript and protein levels of Star, Cyp1 1a1, and Cyp17 but not of transcript level of Hsd3b1 and of transcript and protein levels of Cyp19. The expression of all molecules examined was eventually declined by the ND treatment for 12 weeks, almost certainly due to the disappearance of Leydig cell, which possesses most of steroidogenic enzymes in the testis. Our unreported hormone assay results have shown that a low-dose ND treatment for 2 weeks is sufficient to lead a significant decrease of serum testosterone concentration. Thus, along with molecular biological findings, it is supposed that Cyp11a1 and Cyp17 would be the early responsive molecules of testicular steroidogenic enzymes, involving in the disruption of testicular testosterone synthesis by ND. Further researches are suggested to determine differ- 
ential responsiveness of testicular steroidogenic enzymes to $\mathrm{ND}$ at pre- and/or post-transcriptional levels in detail. In addition, the reduced production of testosterone and the expressional decrease of Cyp 19 in the testis by ND treatment likely lead into the overall reduced synthesis of testicular estrogen. Estrogen involves in regulation of male reproduction, including the function of Sertoli and Leydig cells in the testis and sperm maturation in the efferent ductules and epididymis $[23,25]$. A number of evidence demonstrates the close relationship between the male infertility and disruption of estrogen function $[23,25]$. Thus, it is suggested that some abnormal reproductive parameters obtained by the exposure to ND, including the decreases of semen concentration and spermatozoa motility [13], could be the outcome of a reduced testicular estrogen level.

The exposure to nandrolone could be achieved not only by an injection of nandrolone but also by the ingestion of food containing nandrolone derivatives. The presence of anabolic steroids, including nandrolone, in consumable parts of pork and beef at non-negligible levels is relatively well documented $[26,27]$. Interestingly, Swan et al [28] have shown an inverse relationship between mother's beef consumption during pregnancy and son's semen quality. In addition, a recent study has reported that the semen quality in humans could be negatively affected by increased intake of meat products [29]. Moreover, our earlier research has also shown that orally consumed nandrolone causes germ cell sloughing and abnormal expression of some steroidogenic enzymes in the testis [30]. Therefore, in order to clarify the impact of nandrolone and/or nandrolone-derivatives on the male reproduction, a diverse of contact means to these anabolic steroids should be considered. In conclusion, the exposure to ND, even at a relatively low-dose and/or for a short period, results in the expressional reduction of testicular steroidogenic enzymes at transcript and protein levels, leading to a decrease of testosterone synthesis and consequently poor fertility parameters in male. Special attention should be paid to the effect of AAS or AAS-like materials exposed unintentionally on the male fertility.

\section{CONFLICT OF INTEREST}

We certify that there is no conflict of interest with any financial organization regarding the material discussed in the manuscript.

\section{ACKNOWLEDGMENTS}

Ms. Hee-Jung Seo is deeply thanked for skillful assistance to conduct and complete this experiment. This research was supported by Basic Science Research Program through the National Research Foundation of Korea (NRF) funded by the Ministry of Education (2017R1D1A1B03030209 and
2017R1A2B2007741).

\section{REFERENCES}

1. Scott HM, Mason JI, Sharpe RM. Steroidogenesis in the fetal testis and its susceptibility to disruption by exogenous compounds. Endocr Rev 2009;30:883-925.

2. Bergink EW, Janseen PSL, Turpijn EW, Vander Vies J. Comparison of the receptor-binding properties of nandrolone and testosterone under in vitro and in vivo conditions. J Steroid Biochem Mol Biol 1985;22:831-6.

3. Schwarzenberger F, Toole GS, Christie HL, Raeside JI. Plasma levels of several androgens and estrogens from birth to puberty in male domestic pigs. Acta Endocrinol (Copenh) 1993;128: 173-7.

4. De Wasch K, Le Bizec B, De Brabander H, Andre F, Impens $\mathrm{S}$. Consequence of boar edible tissue consumption on urinary profiles of nandrolone metabolites. II. Identification and quantification of 19-norsteroids responsible for 19-norandrosterone and 19-noretioncholanolone excretion in human urine. Rapid Commun Mass Spectrom 2001;15:1442-7.

5. Busardò FP, Frati P, Sanzo MD, et al. The impact of nandrolone decanoate on the central nervous system. Curr Neuropharmacol 2015;13:122-31.

6. Svechnikov K, Izzo G, Landreh L, Weisser J, Söder O. Endocrine disruptors and Leydig cell function. J Biomed Biotechnol 2010; 2010:Article ID 684504.

7. Karbalay-Doust S, Noorafshan A. Stereological study of the effects of nandrolone decanoate on the rat prostate. Micron 2006;37:617-23.

8. Takahashi M, Tatsugi Y, Kohno T. Endocrinological and pathological effects of anabolic-androgenic steroid in male rats. Endocr J 2004;51:425-34.

9. Nagata S, Kurosawa M, Mima K, et al. Effects of anabolic steroid (19-nortestosterone) on the secretion of testicular hormones in the stallion. J Reprod Fertil 1999;115:373-9.

10. Koeva YA, Georgieva KN, Atanassova PK, Delchev SD. Effects of submaximal training and anabolic androgenic steroids administration on steroidogenic enzyme activity in rat Leydig cells. Folia Med (Plovdiv) 2003;45:37-40.

11. Ahmed MAE. Amelioration of nandrolone decanoate-induced testicular and sperm toxicity in rats by taurine: effects on steroidogenesis, redox and inflammatory cascades, and intrinsic apoptotic pathway. Toxicol Appl Pharmacol 2015;282:285-96.

12. Barone R, Pitruzzella A, Gammazza AM, et al. Nandrolone decanoate interferes with testosterone biosynthesis altering blood-testis barrier components. J Cell Mol Med 2017;21:163647.

13. De Souza GL, Hallak J. Anabolic steroids and male infertility: a comprehensive review. BJU Int 2011;108:1860-65.

14. Gold J, High HA, Li Y, et al. Safety and efficacy of nandrolone decanoate for treatment of wasting in patients with HIV infec- 
tion. AIDS 1996;10:745-52.

15. Yu G, Liu Y, Xie, L, Wang X. Involvement of Sertoli cells in spermatogenic failure induced by carbendazim. Environ Toxicol Pharmacol 2009;27:287-92.

16. Squires EL, Todter GE, Berndtson WE, Pickett BW. Effect of anabolic steroids on reproductive function of young stallions. J Anim Sci 1982;54:576-82.

17. LaVoie HA, King SR. Transcriptional regulation of steroidogenic genes: STARD1, CYP11A1 and HSD3B. Exp Biol Med (Maywood) 2009;234:880-907.

18. Begum-Hasan J, Murphy BE. Influence of 19-nortestosterone and androgens on progesterone biosynthetic enzymes in early human placental explants. J Steroid Biochem Mol Biol 1992; 42:841-8.

19. Pelletier G, Li S, Luu-The V, et al. Immunoelectron microscopic localization of three key steroidogenic enzymes (cytochrome P450(scc), 3 beta-hydroxysteroid dehydrogenase and cytochrome $\mathrm{P} 450(\mathrm{c} 17))$ in rat adrenal cortex and gonads. J Endocrinol 2001;171:373-83.

20. Pomara C Barone R, Marino Gammazza A, Sangiorgi C, et al. Effects of nandrolone stimulation on testosterone biosynthesis in Leydig cells. J Cell Physiol 2016;231:1385-91.

21. Alsiö J, Birgner C, Björkblom L, et al. Impact of nandrolone decanoate on gene expression in endocrine systems related to the adverse effects of anabolic androgenic steroids. Basic Clin Pharmacol Toxicol 2009;105:307-14.

22. Bijlsma JW, Duursma SA, Thijssen JH, Huber O. Influence of nandrolone decanoate on the pituitary-gonadal axis in males. Acta Endocrinol (Copenh) 1982;101:108-12.

23. Carreau S1, Lambard S, Delalande C, et al. Aromatase expression and role of estrogens in male gonad : a review. Reprod Biol Endocrinol 2003;1:35.

24. Nitta H, Bunick D, Hess RA, et al. Germ cells of the mouse testis express P450 aromatase. Endocrinology 1993;132:1396401.

25. Cooke PS, Nanjappa MK, Ko C, Prins GS, Hess RA. Estrogens in male physiology. Physiol Rev 2017;97:995-1043.

26. Van Ginkel LA, Stephany RW, Zoontjes PW, et al. The presence of nortestosterone in edible parts from non-castrated male pigs. Tijdschr Diergeneeskd 1989;114:311-4.

27. Scarth J, Akre C, van Ginkel L, et al. Presence and metabolism of endogenous androgenic-anabolic steroid hormones in meatproducing animals: a review. Food Addit Contam Part A Chem Anal Control Expo Risk Assess 2009;26:640-71.

28. Swan SH, Liu F, Overstreet JW, Brazil C, Shakkebaek NE. Semen quality of fertile US males in relation to their mothers' beef consumption during pregnancy. Hum Reprod 2007;22:1497502.

29. Mendiola J, Torres-Cantero AM, Moreno-Grau JM, et al. Food intake and its relationship with semen quality: a case-control study. Fertil Steril 2009;91:812-8.

30. Dong-Mok Lee, Taesun Min, Inho Choi, et al. Feeding effect of an anabolic steroid, nandrolone, on the male rat testis. AsianAustralas J Anim Sci 2010;23:1566-77. 